Spanish colonial period : the critical study of the scientific work as regards geographical knowledge of Spanish America accomplished by the Supreme Council and the "Casa de Contratacion" of Seville; and fundamental problems in the archæology, ethnography and philology of pre-Columbian America. The subscription has been fixed at 25 pesetas. All communications relating to the Congress should be addressed to S. Jose Maria Torroya, General Secretary, calle del Leon, 21, Madrid.

\section{An Active Sunspot}

A RECEnt feature of interest on the sun's disc has been a group of sunspots that appeared suddenly near the central meridian between August 19 and 20. Its growth is shown as follows, the unit of area being one millionth of the sun's hemisphere :

$\left.\begin{array}{crr}\text { Date } & \text { U.T. } & \text { Area } \\ \text { Aug. } 19^{\mathrm{d}} & 8^{\mathrm{n}} & 0 \\ 20 & 8 & 250 \\ 20 & 11 & 350 \\ 21 & 8 & 700 \\ 22 & 8 & 800\end{array}\right\}$ Heliographic position :

On being observed with the Hale spectrohelioscope at the Royal Observatory, Greenwich, the group was obviously very active, especially about the following times: Aug. $20^{\mathrm{d}} 13 \frac{1}{2}^{\mathrm{h}}$; Aug. $21^{\mathrm{d}} 8 \frac{1}{2}^{\mathrm{h}}$ and $9 \frac{1}{2} \mathrm{~h}-10^{\mathrm{h}}$; Aug. $22^{d} 9^{\text {h }}$. During the time that the spots were under observation, there were also continuous minor changes, often too rapid to record in detail, but sometimes producing quite obvious changes in the configuration of the accompanying hydrogen flocculi in less than an hour. On August 21 a stream of relatively dark hydrogen continued for about two hours from $82^{\mathrm{h}}$ to descend with a radial velocity of $40-50$ $\mathrm{km}$./sec. behind the leader spot. About $10^{\mathrm{h}}$ on the same day, after a portion of the flocculi had shown a sudden brightening, a narrow stream of dark hydrogen was shot upwards with a maximum velocity of 140 $\mathrm{km}$./sec., but this faded in about 10 minutes. If this phenomenon had occurred at the edge of the sun, the profile aspect would doubtless have been an exuptive prominence rising to a considerable height.

\section{The Sky in September}

As an offset to the perceptibly shortening days, September provides in the latitude of the British Isles unexcelled night skies to those who search with binoculars or merely use their eyes. By the middle of the month at $21^{\mathrm{h}}$ U.T. $\left(=22^{\mathrm{h}}\right.$ Summer Time), the great triangle formed by Vega, Deneb, and Altair is not far past culmination, whilst crossing the zenith obliquely to the meridian is the Milky Way-a brilliant sight when the moon does not interfere. Arcturus, nearing the north-west horizon, is balanced by Capella in the north-east, and after midnight the Pleiades, Aldebaran, and the head of Orion make the low eastern sky conspicuous. There are also other gems, such as the tiny constellation, Delphinus, the double star cluster in Perseus, and the well-known double star, $\beta$ Cygni. The moon is full on September 12 at $12^{\mathrm{h}}$, and in this lunation becomes the 'harvest moon'. On September 7 it occults $\lambda$ Sagittarii (magnitude $2 \cdot 9$ ), the disappearance of the star taking place in twilight at $19^{\mathrm{h}} 29.5^{\mathrm{m}}$ and the reappearance at $20^{\mathrm{h}} 35^{\mathrm{m}}$. Saturn is the only planet at all well placed for observation ; in the middle of the month it transits about $23^{\mathrm{h}}$. The ring system appears about half-way open. On September $12^{\mathrm{d}} 3^{\mathrm{h}}$, the planet is in conjunction with the moon. Venus is at inferior conjunction with the sun on September 8, when the planet passes $8^{\circ}$ south of the sun's centre; a thin crescent may then be observed telescopically. The variability of Algol ( $\beta$ Persei) may be observed within about $1 \frac{1}{2}$ hours before and after the following times: September $4^{\mathrm{d}} 23 \cdot 6^{\mathrm{h}}, 7^{\mathrm{d}} 20 \cdot 4^{\mathrm{h}}, 25^{\mathrm{d}} 1 \cdot 3^{\mathrm{h}}$, $27^{\mathrm{d}} 22 \cdot 1^{\mathrm{h}}$ and $30^{\mathrm{d}} 18 \cdot 9^{\mathrm{h}}$. The sun enters the sign Libra (Autumnal Equinox) on September $24^{\mathrm{d}} 0^{\mathrm{h}}$.

\section{Announcements}

Dr. Marshalc A. Howe has been appointed director of the New York Botanical Garden as from October 1, in succession to Dr. E. D. Merrill, who has been appointed head of the Botanical Department, Harvard University. Dr. How has been assistant director of the Gardens since 1923. $\mathrm{He}$ has made several field excursions, especially to Newfoundland and the West Indies, and is an authority on the Hepaticæ and marine Algæ of North America.

THE second International Speech Congress will be held in Brussels on September 6-8, under the presidency of Mlle. Hélène Vacaresco, permanent delegate of Roumania at the League of Nations. The subjects for discussion will be instruction in speech, results obtained by the former congress, international exchange of lectures, and French as a universal language. The fee is 20 franes. Further information can be obtained from L'Agence Joseph Dumoulin, 77-79 Boulevard Adolphe Max, Brussels.

A воок by Dr. F. W. Lanchester on "Relativity" will be published by Messrs. Constable and Co., Ltd., on September 5. It presents the theory of relativity and the relationships of space, time and gravitation, in language suited to those who, though not highly specialised in mathematics, wish to grasp the meaning of four-dimensional space-time.

Applications are invited for the following appointments, on or before the dates mentioned :

An assistant vocational guidance officer to the Kent Education Committee-The Director of Education, Springfield, Maidstone (Sept. 7).

An assistant agricultural organiser to the Notts Education Committee-The Director of Education, Shire Hall, Nottingham (Sept. 11).

A mechanical engineer to the Safety in Mines Research Board-The Under-Secretary for Mines, Establishment Branch, Mines Department, Dean Stanley Street, Millbank, London, S.W.1 (Sept. 14).

An assistant librarian in the University of Aberdeen-The Secretary (Sept. 30).

A research fellow, two junior research assistants, and three junior laboratory assistants to the Wool Industries Research Association-The Secretary, Torridon, Headingley, Leeds, 6. 